\title{
Evaluation of Sampling Techniques on Tall-Grass Prairie
}

\author{
DONALD A. BECKER AND JERRY J. CROCKETT
}

Highlight: An evaluation of sampling techniques was conducted on a tall-grass prairie in eastern Oklahoma. The point transect, a modified point transect, line transect, angle order, quarter, quadrat, and wandering quarter methods were used. Relative and total density values were determined and compared with actual values obtained by hand count. The above methods, with the exception of the quadrat, underestimated the relative density of splitbeard bluestem (Andropogon ternarius), a dominant and densely cloned species, and overestimated switchgrass (Panicum virgatum), a subdominant, single-stalked species. Relative and total density values obtained by the quarter method were significantly less accurate than those obtained by the other methods; no method was significantly more accurate. With recalculation excluding splitbeard bluestem data, relative densities obtained by most of the methods agreed more closely with actual values, and the quarter method was again significantly less accurate. Results indicated that degree of clone density of the dominants and subdominants, as well as sampling time, should be noted prior to the selection of a sampling method in a highly aggregated grassland type. The modified point transect or quadrat methods are considered to be most applicable if the dominants are densely cloned as in splitbeard bluestem; however, the point transect or line transect methods may be adequate if the dominants are sparsely-cloned as in big bluestem (Andropogon gerardi) or little bluestem (Andropogon scoparius).

The quadrat method is one of the oldest and most widely used methods for grassland analysis. Other methods, however, have been developed to avoid much of the sampling time needed to obtain statistically reliable results. These methods include the meter-line transect (Weaver and Clements, 1929); point transect (Levy and Madden, 1933); loop (Parker, 1951); and quarter (Dix, 1961). Whitman and Siggeirsson (1954) compared the line and point transect methods in a mixed grassland type in North Dakota and considered both to be equally reproducible. Johnston (1957) compared the point transect, line transect, and loop methods in a mixed grassland type in Alberta. The loop method was found to be least reproducible and a preference was indicated for the point transect

The authors are assistant professor of biology in the Department of Biology, Midland Lutheran College, Fremont, Nebraska, and associate professor of plant ecology in the Department of Botany and Plant Pathology, Oklahoma State University, Stillwater.

This work was done while the senior author was a participant in a NSF Summer Research Participation Program in botany at Oklahoma State University during the summer of 1970 .

The authors wish to acknowledge Dr. Gerald M. Funk for assistance with statistical procedures.

Manuscript received December 31, 1971. method. Crockett (1963) compared the line transect, point transect, and quarter methods in a tall grassland type in Oklahoma and indicated a preference for the point transect method. More recently, density data obtained by the quarter method was compared to quadrat data for tall grassland types in Wisconsin (Risser and Zedler, 1968) and in Minnesota (Good and Good, 1971). In these studies the quarter method results did not closely agree with those of the quadrat method, particularly in aggregated stands.

The above studies were somewhat limited in scope in that only a few methods were compared in a stand, and sampled and actual counts were not made to determine accuracy. Nor were methods for non-random populations, the angle order (Morisita, 1957) and wandering quarter (Catana, 1963) compared with those best adapted for random population.s (quarter, line transect, quadrat). The objectives of this study were to compare the field adaptability of methods in a highly aggregated tall-grass prairie; to determine accuracy by comparing actual and sampled data for the various methods; and to determine if accuracy of methods for non-random populations was greater than those for random populations.

\section{Methods}

The study site was located in an upland prairie, approximately $11 \mathrm{~km}$ west of Stillwater, Okla. By visual inspection the stand appeared homogeneous and contained as a dominant splitbeard bluestem (Andropogon ternarius), and as subdominants switchgrass (Panicum virgatum), little bluestem (A. scoparius), big bluestem ( $A$. gerardi), and broomsedge ( $A$. virginicus). The vegetation was approximately $30-60 \mathrm{~cm}$ high when sampled in July of 1970 , and a $4-8 \mathrm{~cm}$ mulch layer was present. Four plots, each $1.2 \times 5 \mathrm{~m}$, were systematically established and numbered 1-4. Each was subdivided at 20 $\mathrm{cm}$ intervals by imaginary coordinates projected from stakes on the plot margins. Four sampling methods were used on these plots; the point transect (10 pins), the meter-line transect, the quarter, and the angle order. On plots 3 and 4 three other methods were used: a modification of the point transect, whereby all basal contacts made by each pin were counted; a $10 \times 10 \mathrm{~cm}$ open-ended quadrat; and the wandering quarter. Relative density (percentage composition) for each major species was determined by all of the above methods, relative frequency (frequency value of a species divided by total of frequency values for all species) by all except the wandering quarter, and total density by all except the point transect and wandering quarter methods.

The sampling units were randomized on each of the plots by the selection of a series of numbers, each of which represented a particular coordinate intersection. Sampling on each plot was terminated when approximately 400 shoots were encountered. A hit or contact by the point transect methods was determined when a shoot was hit within 0.5 $\mathrm{cm}$ of ground level, and by the line transect method when a shoot was found within a $0.5 \mathrm{~cm}$ strip on either side of a 1 $\mathrm{mm}$ cord stretched tightly between two pins. After sampling, vegetation was removed from the plot and all shoots counted to determine the actual relative 
and total density.

Determination of total density in the quarter and angle order methods followed Dix (1961) and Morisita (1957), respectively. In the latter method two estimates are determined, $\overline{\mathrm{m}}_{1}$ and $\overline{\mathrm{m}}_{2}$. If $\overline{\mathrm{m}}_{1}$ is greater than $\overline{\mathrm{m}}_{2}, \frac{\overline{\mathrm{m}}_{1}}{\pi}$ is considered as the best density estimate; if $\overline{\mathrm{m}}_{1}$ is less than $\overline{\mathrm{m}}_{2}$, the average of the two estimates $\overline{\mathrm{m}}_{\mathrm{o}}$ is determined, and $\frac{\overline{\mathrm{m}}_{\mathrm{o}}}{\pi}$ is considered as the best estimate of density.

Since both sampled and actual data were collected, the sampled and actual ratios of the populations could be compared by the chi-square statistic given by the formula:

where

$$
\chi^{2}=\sum \frac{\left(x_{\text {obs }}-x_{\text {exp }}\right)^{2}}{X_{\text {exp }}}
$$

$\chi^{2}=$ the chi-square value

$\sum=$ the summation of the ratios obtained when observed and actual data for each species or group of species (i.e., forbs and miscellaneous grasses) were compared. Since there were seven species or groups of species (including splitbeard bluestem) and six species or groups of species excluding it, seven or six ratios were summed to obtain the respective chi-square value.
$X_{\text {obs }}=$ the number of shoots of a species on a particular plot encountered by the sampling method.

$X_{\exp }=$ the sum total of shoots of all species encountered in that plot multiplied by the actual relative density of that species.

The chi-square values for each method on all four plots were compared for significance by nonparametric procedures: the Friedman statistic (Bradley, 1968), or the Kruskall-Wallis statistic (Siegel, 1956).

Two indices of aggregation were calculated to determine vegetation pattern. These included the index of nonrandomness (Pielou, 1959) and the variance: mean ratio (Blackman, 1942). The former is determined from the relation $\alpha=\pi \mathrm{D} \omega$, where $\omega$ is the mean square of the point to plant distances of the quarter method and D is the density of plants determined by actual counts. The latter index was calculated from quadrat data, and could be determined on plots 3 and 4 only. In both indices, values in excess of 1.0 indicate aggregation.

\section{Results \\ Density}

Sampled values of relative density did not closely approximate actual values for the major species by the methods used (Table 1). On all plots most of the methods, but particularly the quarter, underestimated the relative density of splitbeard bluestem, a densely-cloned species, and overestimated switchgrass, a single-stalked species. The latter was best estimated by the quadrat method. Loosely-cloned species such as little bluestem and big bluestem were underestimated by the quarter method but not by the point transect, line transect, or angle order methods. Other species or groups such as broomsedge bluestem, miscellaneous grasses, and forbs were not at all or only slightly underestimated by the point transect, line transect, and angle order techniques; however, the quarter method grossly overestimated the singlestalked miscellaneous grasses and forbs. Chi-square values calculated for the point transect, line transect, and angle order methods were approximately equivalent, while those of the quarter method were much higher (Table 2). Only the chisquare value of 11.59 on plot 4 with the line transect method indicated a good fit between actual and sampled data $(\mathrm{P}=$ $.05)$. When the chi-square values were ranked and compared by the Friedman test, however, only the values obtained by the quarter method were significantly less accurate $(P=.05)$. Splitbeard blue-

Table 1. A comparison of sampled and actual density values (\%) obtained by the sampling methods. ${ }^{1}$

\begin{tabular}{|c|c|c|c|c|c|c|c|c|c|}
\hline Species & Plot & $\begin{array}{l}\text { Actual } \\
\text { relative } \\
\text { density }\end{array}$ & $\begin{array}{c}\text { Point } \\
\text { transect }\end{array}$ & $\begin{array}{c}\text { Line } \\
\text { transect }\end{array}$ & $\begin{array}{c}\text { Angle } \\
\text { order }\end{array}$ & Quarter & $\begin{array}{l}\text { Modified } \\
\text { point } \\
\text { transect }\end{array}$ & Quadrat & $\begin{array}{c}\text { Wandering } \\
\text { quarter }\end{array}$ \\
\hline Splitbeard bluestem & $\begin{array}{l}1 \\
2 \\
3 \\
4\end{array}$ & $\begin{array}{l}62.7 \\
51.9 \\
51.9 \\
37.5\end{array}$ & $\begin{array}{l}46.8 \\
40.8 \\
30.2 \\
26.3\end{array}$ & $\begin{array}{l}56.3 \\
40.1 \\
36.9 \\
30.0\end{array}$ & $\begin{array}{l}52.8 \\
47.0 \\
29.6 \\
31.5\end{array}$ & $\begin{array}{l}43.8 \\
37.8 \\
20.3 \\
22.0\end{array}$ & $\begin{array}{c}- \\
3 \overline{8.9} \\
32.1\end{array}$ & $\begin{array}{r}- \\
- \\
45.3 \\
29.4\end{array}$ & $\begin{array}{c}- \\
\overline{-} \\
36.6 \\
34.2\end{array}$ \\
\hline Switchgrass & $\begin{array}{l}1 \\
2 \\
3 \\
4\end{array}$ & $\begin{array}{l}10.1 \\
16.5 \\
19.0 \\
15.7\end{array}$ & $\begin{array}{l}19.9 \\
19.6 \\
24.0 \\
19.0\end{array}$ & $\begin{array}{l}19.5 \\
23.2 \\
27.0 \\
17.4\end{array}$ & $\begin{array}{l}18.5 \\
24.8 \\
34.6 \\
24.8\end{array}$ & $\begin{array}{l}31.3 \\
31.8 \\
43.3 \\
39.0\end{array}$ & $\begin{array}{c}- \\
- \\
20.9 \\
20.3\end{array}$ & $\begin{array}{c}- \\
\overline{18.3} \\
15.3\end{array}$ & $\begin{array}{c}- \\
- \\
31.8 \\
17.6\end{array}$ \\
\hline Little bluestem & $\begin{array}{l}1 \\
2 \\
3 \\
4\end{array}$ & $\begin{array}{r}8.0 \\
17.4 \\
10.5 \\
21.3\end{array}$ & $\begin{array}{r}8.7 \\
17.9 \\
19.1 \\
25.1\end{array}$ & $\begin{array}{r}6.0 \\
17.4 \\
18.4 \\
25.6\end{array}$ & $\begin{array}{r}8.5 \\
13.8 \\
12.3 \\
20.0\end{array}$ & $\begin{array}{r}6.8 \\
11.0 \\
8.3 \\
12.3\end{array}$ & $\begin{array}{c}- \\
\overline{-} \\
17.3 \\
26.7\end{array}$ & $\begin{array}{c}- \\
\overline{-} \\
19.7 \\
28.5\end{array}$ & $\begin{array}{c}- \\
\overline{4} .5 \\
14.5\end{array}$ \\
\hline Big bluestem & $\begin{array}{l}1 \\
2 \\
3 \\
4\end{array}$ & $\begin{array}{r}13.3 \\
4.1 \\
7.6 \\
15.4\end{array}$ & $\begin{array}{r}15.9 \\
4.1 \\
11.4 \\
16.1\end{array}$ & $\begin{array}{r}11.8 \\
7.5 \\
7.6 \\
16.4\end{array}$ & $\begin{array}{r}12.0 \\
2.5 \\
6.3 \\
11.5\end{array}$ & $\begin{array}{l}9.5 \\
2.0 \\
4.8 \\
8.0\end{array}$ & $\begin{array}{c}- \\
\overline{0} \\
10.6 \\
16.1\end{array}$ & $\begin{array}{r}- \\
- \\
4.6 \\
14.6\end{array}$ & $\begin{array}{c}- \\
\overline{6} .1 \\
24.5\end{array}$ \\
\hline Broomsedge bluestem & $\begin{array}{l}1 \\
2 \\
3 \\
4\end{array}$ & $\begin{array}{l}0.8 \\
2.2 \\
4.0 \\
2.0\end{array}$ & $\begin{array}{l}1.5 \\
3.1 \\
6.2 \\
4.6\end{array}$ & $\begin{array}{l}0.2 \\
0.7 \\
1.8 \\
1.7\end{array}$ & $\begin{array}{l}1.3 \\
2.3 \\
5.8 \\
3.8\end{array}$ & $\begin{array}{l}1.5 \\
1.5 \\
3.8 \\
5.3\end{array}$ & $\begin{array}{l}- \\
\overline{6} .0 \\
2.0\end{array}$ & $\begin{array}{l}- \\
- \\
3.9 \\
1.5\end{array}$ & $\begin{array}{l}- \\
\overline{3.8} \\
1.5\end{array}$ \\
\hline Miscellaneous grasses & $\begin{array}{l}1 \\
2 \\
3 \\
4\end{array}$ & $\begin{array}{l}3.5 \\
5.3 \\
4.4 \\
5.2\end{array}$ & $\begin{array}{r}3.8 \\
12.2 \\
6.4 \\
5.1\end{array}$ & $\begin{array}{l}4.3 \\
7.5 \\
5.6 \\
5.2\end{array}$ & $\begin{array}{l}4.8 \\
7.0 \\
5.3 \\
4.5\end{array}$ & $\begin{array}{r}5.3 \\
10.0 \\
12.3 \\
5.5\end{array}$ & $\begin{array}{l}- \\
\overline{4.8} \\
1.5\end{array}$ & $\begin{array}{l}- \\
\overline{2} .7 \\
6.3\end{array}$ & $\begin{array}{l}- \\
\overline{4} .1 \\
4.6\end{array}$ \\
\hline Forbs & $\begin{array}{l}1 \\
2 \\
3 \\
4\end{array}$ & $\begin{array}{l}1.8 \\
2.7 \\
2.6 \\
2.9\end{array}$ & $\begin{array}{l}3.3 \\
2.3 \\
2.7 \\
3.7\end{array}$ & $\begin{array}{l}2.4 \\
3.5 \\
2.7 \\
3.7\end{array}$ & $\begin{array}{l}2.3 \\
2.3 \\
6.3 \\
4.0\end{array}$ & $\begin{array}{l}2.0 \\
6.3 \\
7.5 \\
8.0\end{array}$ & $\begin{array}{l}- \\
- \\
1.7 \\
1.5\end{array}$ & $\begin{array}{l}- \\
\overline{5} .6 \\
4.3\end{array}$ & $\begin{array}{l}- \\
- \\
3.1 \\
3.1\end{array}$ \\
\hline
\end{tabular}

${ }_{1}$ The quadrat, modified point transect, and wandering quarter methods were used on plots $3-4$ only.

$2 \mathrm{n}=3 ; \mathrm{k}=4$ (see Morisita, 1957). 
Table 2. Chi-square values determined from actual and sampled density data. Values for each method on each plot are given as well as average and overall values. ${ }^{1}$

\begin{tabular}{|c|c|c|c|c|c|c|c|}
\hline Plot & $\begin{array}{c}\text { Point } \\
\text { transect }\end{array}$ & $\begin{array}{c}\text { Line } \\
\text { transect }\end{array}$ & $\begin{array}{l}\text { Angle } \\
\text { order }\end{array}$ & Quarter & $\begin{array}{c}\text { Modified } \\
\text { point } \\
\text { transect }\end{array}$ & Quadrat & $\begin{array}{c}\text { Wandering } \\
\text { quarter }\end{array}$ \\
\hline \multicolumn{8}{|c|}{ Including splitbeard bluestem } \\
\hline 1 & 63.3 & 45.0 & 38.1 & 211.3 & - & - & - \\
\hline 2 & 52.9 & 44.5 & 26.6 & 73.5 & - & - & - \\
\hline 3 & 86.6 & 67.7 & 115.8 & 299.7 & 43.3 & 57.3 & 59.3 \\
\hline$\underline{4}$ & 34.8 & 11.6 & 37.2 & 250.8 & 27.7 & 20.7 & 32.3 \\
\hline$\overline{\mathrm{x}}$ & 58.2 & 42.2 & 54.6 & 206.5 & 35.5 & 39.0 & 45.8 \\
\hline $0 x^{2}$ & 166.1 & 110.3 & 175.1 & 764.6 & 56.2 & 63.7 & 52.9 \\
\hline \multicolumn{8}{|c|}{ Excluding splitbeard bluestem } \\
\hline 1 & 15.7 & 31.5 & 17.4 & 100.9 & - & - & - \\
\hline 2 & 23.7 & 16.7 & 20.9 & 68.5 & - & - & - \\
\hline 3 & 7.1 & 20.6 & 24.6 & 83.8 & 11.6 & 44.4 & 17.1 \\
\hline 4 & 11.0 & 1.7 & 28.3 & 168.0 & 20.9 & 8.6 & 29.0 \\
\hline$\overline{\mathrm{x}}$ & 14.4 & 17.6 & 22.8 & 105.3 & 16.2 & 26.5 & 23.1 \\
\hline $0 x^{2}$ & 9.2 & 27.9 & 78.1 & 349.4 & 22.0 & 39.3 & 19.8 \\
\hline
\end{tabular}

${ }^{1}$ The overall chi-square value for plots $1-4$ or $3-4$ is indicated by $0 \chi^{2}$.

stem, a species with dense clumps, appeared to contribute to the poor agreement of sampled and actual data, and data were recalculated with its exclusion. Subsequently, the recalculated data for the major species (switchgrass, little bluestem, big bluestem) coincided to a greater degree with actual values, particularly for the point and line transect methods, but not as markedly for the quarter method. Chi-square values from the point transect, line transect, and angle order methods tended to be considerably lower than those of the quarter method (Table 2). Ranking and comparing the chi-square values from plots 1-4 with the Friedman statistic, again indicated the quarter method was significantly less accurate, but there were no significant differences between the angle order, point transect, and line transect methods.

On plots 3 and 4 somewhat better agreement between actual and sampled data for three of the major species (switchgrass, splitbeard bluestem, and big bluestem) was obtained by the quadrat and modified point transect methods, but not for the wandering yuarter method. In fact, lower average ar,d overall chi-square values for plots 3 and 4 were obtained by the modified point transect and quadrat methods than by all other methods (Table 2). To enable statistical comparison between all methods (except the quarter method) on plots 3-4 only, the results were divided into 10 subgroups, five for each plot. With subsequent recalculation of chi-square values, ranking, and application of the Friedman statistic, no significant difference was found $(\mathrm{P}<0.20)$. Exclusion of splitbeard bluestem data also resulted in a better fit of sampled and actual data for the major species by the three above methods. Lower chi- square values were also obtained by the modified point transect method, but these again were not significantly more accurate.

Actual and sampled total density values are given in Table 3. To enable statistical comparison, each of the plot results was divided into five subgroups. Chi-square values were then calculated, ranked, and compared by the KruskallWallis test. Density estimates obtained by the quarter method were significantly less accurate $(P=.001)$. Sampled values from the quadrat method were closest to actual values unless the 28 measurements $1 \mathrm{~cm}$ or less were excluded from the $\frac{\overline{\mathrm{m}}_{1}}{\pi}$ density estimate of the angle order method (Table 3 ). When the sum of reciprocals of these numbers was included, the estimate $\frac{\overline{\mathrm{m}}_{1}}{\pi}$ was disproportionately increased and density was greatly overestimated. The estimate excluding the 28 measurements, $\frac{\overline{\mathrm{m}}_{1 \mathrm{ex}}}{\pi}$, was significantly more accurate than those obtained by $\frac{\overline{\mathrm{m}}_{1}}{\pi}, \frac{\overline{\mathrm{m}}_{\mathrm{o}}}{\pi}$, or by

Table 3. Comparison of total density values (plant $\mathrm{s} / \mathrm{m}^{2}$ ) obtained from some sampling techniques.

\begin{tabular}{lcccrrrr}
\hline & & & & & \multicolumn{3}{c}{ Angle order } \\
\cline { 5 - 7 } Plot & $\begin{array}{l}\text { Actual } \\
\text { density }\end{array}$ & $\begin{array}{c}\text { Line } \\
\text { transect }\end{array}$ & Quarter & Quadrat & $\frac{{ }^{*} \overline{\mathrm{m}}_{1 \mathrm{ex}}}{\pi}$ & ${ }^{* *} \overline{\mathrm{m}}_{1}$ & ${ }^{* * *} \overline{\mathrm{m}}_{\mathrm{o}}$ \\
\hline 1 & 1000.5 & 836.0 & 372.2 & - & 1000.5 & 1897.1 & 1321.3 \\
2 & 1073.4 & 870.0 & 404.0 & - & 952.6 & 1143.6 & 877.2 \\
3 & 983.3 & 1310.0 & 535.6 & 1056.0 & 916.6 & 1362.5 & 980.1 \\
4 & 889.7 & 1382.0 & 376.1 & 962.0 & 819.8 & 1966.3 & 1350.1 \\
$\overline{\mathrm{x}}$ & 986.7 & 1099.5 & 422.0 & 1009.0 & 923.6 & 1592.4 & 1132.2 \\
\hline
\end{tabular}

${ }^{*} \overline{\mathrm{m}}_{\frac{1 \mathrm{ex}}{\pi}}$ was calculated by excluding distance measurements one cm or less.

${ }^{* *} \frac{\pi}{\pi}$ was calculated by including all distance measurements.

*** $\frac{\bar{m}_{0}}{\pi}$ is the average of $m_{1}$ and $m_{2}$ divided by $\pi$. 
decrease in the aggregation indices and in relative density of splitbeard bluestem, the most aggregated species, is also indicated in Table 4.

The methods varied considerably in sampling time and could be ranked according to decreasing time requirements as follows: point transect, line transect, angle order, wandering quarter, quarter and quadrat. Approximately 400 shoots could be encountered by the quadrat method in one-half less time than in the point transect method. Sampling time for both the point and line transect methods was increased because of the mulch layer; in addition, the high density of splitbeard clumps $\left(5-6\right.$ shoots $\left./ \mathrm{cm}^{2}\right)$ hampered sampling in the latter. In the angle order method much time was spent in locating the third nearest individual and calculating total density.

\section{Discussion}

The composition of an aggregated grassland community theoretically can best be determined by a single pin of infinitely small size as a sampling unit, which is repeatedly lowered into the vegetation, striking the shoots of each species. In a random sample the probability of hitting shoots of each species is proportional to their density. Since only sampling error would be present, the observed values should closely approximate the expected values. The chi-square values obtained by such a method should not exceed 12.59, with six degrees of freedom at $\mathrm{P}=.05$ (Snedecor and Cochran, 1967). The poor agreement of sampled and actual data in this study indicates considerable bias in the sampling methods. High aggregation of some species is believed to contribute to much of the poor agreement. Splitbeard bluestem was an especially aggregated species; a decrease in its density coincided with a decrease in magnitude of Pielou's index on plots 1-4. In addition, sampled values departed less from actual values for major species when splitbeard bluestem data were excluded. With its inclusion the chi-square value of 12.59 was not or was slightly exceeded only by the modified point transect method on plot 3 and 4 , and by the line transect method on plot 4. With its exclusion, however, the maximum expected chi-square value of 11.07 (5 degrees of freedom at $\mathbf{P}=.05$ ) was obtained on plot 3 by both of the point transect methods, and on plot 4 by the point transect, line transect, and quadrat methods.

Density data obtained by the quarter method were significantly less accurate

Table 4. Two measures of aggregation. All index values are significant at $P=.01$.

\begin{tabular}{cccc}
\hline \hline Plot & Pielou's index & Variance: mean $^{1}$ & $\begin{array}{l}\text { Rel. density of split- } \\
\text { beard bluestem (\%) }\end{array}$ \\
\hline 1 & 11.05 & - & 62.7 \\
2 & 9.97 & - & 51.9 \\
3 & 8.90 & 10.10 & 51.9 \\
4 & 7.96 & 4.39 & 37.5 \\
\hline
\end{tabular}

1 Quadrat data were obtained only for plots 3 and 4.

than those obtained by the other methods. The quarter method was originally developed to sample dispersed forest vegetation, but subsequently was used in grasslands by Dix (1961). The reliability of this method for grasslands was evaluated in several studies in which quarter method density data were compared to either actual or quadrat counts. In the Arizona desert grassland and California grassland types, Morris (1962) found the quarter method grossly underestimated density. In Wisconsin, Risser and Zedler (1968) found that density was grossly underestimated for stands dominated by aggregated species such as little bluestem, big bluestem, prairie dropseed (Sporobolus heterolepis), or hairy grama (Bouteloua hirsuta). In Minnesota, Good and Good (1971) found that the quarter method underestimated density in xeric stands dominated by grama grass (Bouteloua gracilis), needleandthread (Stipa comata), and in mesic stands dominated by big bluestem and Kentucky bluegrass (Poa pratensis).

In this study better results were obtained by distance methods other than the quarter method; for example, the wandering quarter for relative density, and the angle order for total density. The accuracy of the estimates of the latter, however, depended upon whether $\frac{\overline{\mathrm{m}}_{1 \mathrm{ex}}}{\pi}$ $\frac{\overline{\mathrm{m}}_{1}}{\pi}$, or $\frac{\overline{\mathrm{m}}_{\mathrm{o}}}{\pi}$ was used. In this study the estimate $\overline{\mathrm{m}}_{1}$ was greater than $\overline{\mathrm{m}}_{2}$ in all plots, and according to Morisita (1957), $\frac{\overline{\mathrm{m}}_{1}}{\pi}$ should be used as the density estimate. However, only $\frac{\overline{\mathrm{m}}_{1 \mathrm{ex}}}{\pi}$ gave a good density estimate; and it was significantly more accurate than $\frac{\overline{\mathrm{m}}_{1}}{\pi}, \frac{\overline{\mathrm{m}}_{\mathrm{o}}}{\pi}$, or the line transect method. In a desert grassland type in Arizona, Morris (1962) compared angle order density data with that obtained by quadrat and actual counts. In that study, despite the fact that $\overline{\mathrm{m}}_{1}$ was greater than $\overline{\mathrm{m}}_{2}, \frac{\overline{\mathrm{m}}_{\mathrm{o}}}{\pi}$ rather than $\frac{\overline{\mathrm{m}}_{1}}{\pi}$ gave the better density estimate.

The three additional methods used on plots 3 and 4, when compared with the other methods, were not significantly different. One of these, the modified point transect method, does appear to have less bias in this highly aggregated grassland type because, on the average, chi-square values calculated from the 10 subgroups of relative density data were lower. When splitbeard bluestem data were omitted, however, the modified point transect did not appear to have any advantage over the line transect and point transect methods. These latter methods may give accurate results when used to sample species with loose clones such as big bluestem and little bluestem.

The choice of a particular method for sampling grassland vegetation should be based not only on growth form, but also on the degree of aggregation of the dominant and subdominant species. Accuracy, as well as time and reproduceability, should also be considered. In this grassland type the quadrat method appeared to have advantages over the other methods when time was considered, but did not appear to be as accurate as the point transect method. The development of better techniques to assess density and percentage composition of highly aggregated species is needed to facilitate studies in aggregated grassland communities.

\section{Literature Cited}

Blackman, G. E. 1942. Statistical and ecological studies in the distribution of species in plant communities. I. Dispersion as a factor in the study of changes in plant populations. Ann. of Bot. 6:351-370.

Bradley, J. E. 1968. Distribution-free statistical tests Prentice-Hall, Inc., Englewood Cliffs, N. J. 338 p.

Catana, A. J., Jr. 1963. The wandering quarter method of estimating population density. Ecology 44:349-360.

Crockett, J. J. 1963. Preliminary studies in the evaluation of grassland sampling techniques in tall-grass prairie sites. Proc. Okla. Acad. Sci. 43:43-46.

Dix, R. L. 1961. An application of the pointcentered quarter method to the sampling of grassland vegetation. J. Range Manage. $14: 63-69$.

Good, R. E., and N. F. Good. 1971. Vegetation of a Minnesota prairie and a comparison of methods. Amer. Mid. Nat. 85:228-231. 
Johnston, A. 1957. A comparison of the line interception, vertical point quadrat, and loop methods as used in measuring basal area of grassland vegetation. Can. J. Plant Sci. 37:35-42.

Levy, E. B., and E. A. Madden. 1933. The point method of positive analysis. N. Z. J. Agr. 46:267-279.

Morisita, M. 1957. A new method for the estimation of density by the spacing method applicable to non-randomly distributed populations. Physiol. and Ecology 7:134-144. Transl. published by Nat. Res. Council of Canada, Tech. Transl. 1167.
Ottawa, 1965.

Morris, M. 1962. In:Strickler, G. S., and F. W. Stearns. The determination of plant density. U. S. Dep. Agr. Misc. Pub. 940. 172 p. (p. 30-40).

Parker, K. W. 1951. A method for measuring trend in range condition on national forest ranges. Administrative Studies, U. S. Forest Serv., Washington, D. C. 26 p. Processed.

Pielou, E. C. 1959. The use of point-to-plant distances in the study of the pattern of plant populations. J. Ecol. 47:607-613.

Risser, P. G., and P. H. Zedler. 1968. An evaluation of the grassland quarter method.
Ecology 49:1006-1009.

Siegel, S. 1956. Nonparametric statistics. McGraw-Hill Book Company, Inc., New York. $312 \mathrm{p}$.

Snedecor, G. W., and W. G. Cochran. 1967. Statistical methods. Sixth Edition. Iowa State Univ. Press, Ames. 539 p.

Weaver, J. E., and F. E. Clements. 1929. Plant ecology. McGraw-Hill Book Company, Inc. $520 \mathrm{p}$.

Whitman, W. C., and E. I. Siggeirsson. 1954. Comparison of line interception and point contact methods in the analysis of mixed grass range vegetation. Ecology 35:431 436 . 